Article

\title{
Enhancing Green Building Rating of a School under the Hot Climate of UAE; Renewable Energy Application and System Integration
}

\author{
Joud Al Dakheel, Kheira Tabet Aoul * (D) and Ahmed Hassan (D) \\ Architectural Engineering Department, United Arab Emirates University, P.O. Box, 15551 Al Ain, UAE; \\ jude_d91@hotmail.com (J.A.D.); ahmed.hassan@uaeu.ac.ae (A.H.) \\ * Correspondence: kheira.anissa@uaeu.ac.ae; Tel.: +971-566-433-648
}

Received: 2 March 2018; Accepted: 5 July 2018; Published: 17 September 2018

\begin{abstract}
Similar to many fast growing countries, the United Arab Emirates (UAE) witnessed fast population and urbanization growth. The building sector accounts for a major share of its electricity consumption, reaching up to $70 \%$. To encourage sustainable development and reduce energy consumption and emissions, the government introduced a sustainability initiative called "Estidama", which employs the use of the Pearl Building Rating System (PBRS). Government buildings, which constitute $20 \%$ of the built environment, aim to lead the way, and are therefore required to attain a high level of achievement, based on their PBRS ranking (minimum of two out of five pearls). Schools, led by Abu Dhabi Educational Council (ADEC), are governmental buildings and aim to attain a higher level of achievement (three out of five pearls). The ADEC plans to build one hundred schools to be built by 2020, through its Future Schools Program. Over half of the schools have been completed, but only $20 \%$ reached the targeted rating (of three out of five pearls). The Renewable Energy (RE) application in the UAE is minimal, although it represents $25 \%$ of the local rating code. The objective of this paper is to explore the sustainable performance of one representative school that did not reach the desired green rating level, with the objective to assess opportunities for an enhanced performance. This is done through testing the performance and the application of three RE systems comprising of photovoltaics (PV) array, an absorption cooling system and a geothermal cooling system through Transient Systems Simulation (TRNSYS) software. Cumulatively, implementation of these options results in RE potentially contributing to $19 \%$ of the school's annual energy consumption, enhancing the school's performance by up to 14 additional credit points, and reaching the target level of achievement (a three pearl rating). Furthermore, system integration of RE into the existing school were also considered. Results indicate the significant potential of integrating RE systems in future schools in hot climatic contexts, for an improved energy performance.
\end{abstract}

Keywords: building energy performance; green building rating system; photovoltaic; solar absorption chiller; geothermal; schools; UAE; TRNSYS

\section{Introduction}

Fast growing economies often share common traits in terms of population growth and rapid urbanization, resulting in high energy demand and significant carbon emissions. Abu Dhabi, the capital of the United Arab Emirates (UAE), has similarly experienced a sharp increase in energy demand, leaping from $25,423 \mathrm{GWh}$ in 2005 to $62,248 \mathrm{GWh}$ in 2015. This drove similar increases in generation capacity, as indicated in Figure 1 [1]. The surge in energy consumption, positions the UAE as one of the world's largest energy consumers per capita, with the building sector accounting for almost $70 \%$ of its total electrical energy consumption [2]. The primary electricity loads in the UAE are, by far, 
cooling demand, then lighting, refrigeration and other appliance loads. In Abu Dhabi, the residential electricity load distribution is $47 \%$ for cooling (but can exceed $60 \%$ during the summer peak), $7 \%$ for lighting, 3\% for refrigeration and 35\% for other appliance loads [3]. The UAE's extreme hot climate, and subsequently high cooling demand, generated a challenging environment for energy conservation and environmental sustainability of buildings [4].

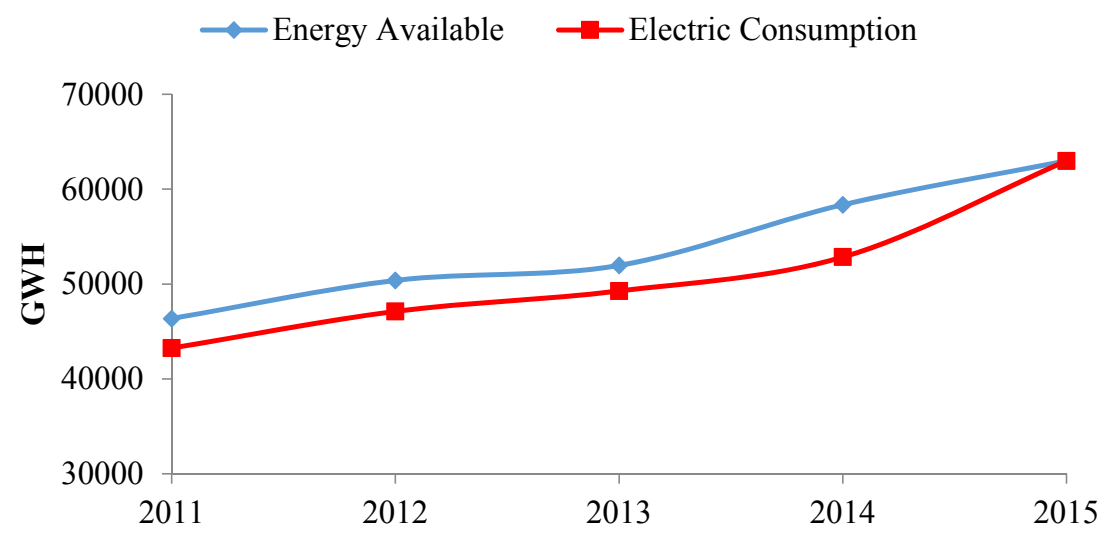

Figure 1. Total electricity power production in the Abu Dhabi emirate [1].

In line with worldwide initiatives to implement energy efficiency strategies in buildings, the UAE government introduced in 2008 a stringent sustainability code, named "Estidama" [5]. Followed in 2010 by the development of a green building rating system, named the Pearl Building Rating System (PBRS). The latter aligns with the principles of international green building rating systems, aiming to promote the development of sustainable buildings. The code compliance is governed by the PBRS, ranging from one to five pearls, ranking the level of achievements across seven categories. Similarly to most green rating system, PBRS is comparable with Leadership in Energy and Environmental Design (LEED) and Building Research Establishment Environmental Assessment Method (BREEAM) rating systems. It rates buildings based on six categories: (1) Integrated Development Process (10 credit points), (2) Natural Systems (14 credit points), (3) Livable Communities (35 credit points), (4) Precious Water (37 credit points), (5) Resourceful Energy (42 credit points), and (6) Stewarding Materials (19 credit points)]. The first level of a building attainment requires meeting all mandatory credits and would gain one pearl, while if it achieves 60 additional credits it will reach the second level of attainment (or two pearls). Reaching 85 credits will achieve the third level or three pearls, while 115 credits translates to four pearls, and 140 credits qualifies for five pearls, which is the maximum number of pearls. The PBRS has a manual with specific guidelines on the methodology and calculation equations that are used to validate each system in order to achieve the credits [6].

The Precious Water and Renewable Energy categories are the dominant categories, comprising of the highest number of credit points. Twenty five percent of each of these categories represents a response to the context: characterized by scarcity of water and the extreme harsh climate that requires a substantial amount of cooling. The UAE has one of the highest sun exposure rates in the world, giving it a high potential for renewable energy development [7]. The application of RE in the UAE has been minimal and needs to be reinforced more in buildings in order to overcome the current energy challenges. Renewable energy makes up less than $0.1 \%$ of the UAE's total final energy consumption, which is unsustainable due to global current energy consumption challenges [8]. The UAE's RE energy base was non-existent in 2008. Since then, approximately 150 megawatt (MW) of solar panels have been installed, and over 300 additional MW have been announced. A further $100 \mathrm{MW}$ of solar photovoltaic (PV) in Dubai, and 53 MW of waste-to-energy in Sharjah, was constructed. Nevertheless, in the context of other Gulf Cooperation Countries (GCC), the UAE has maintained the lead in total contracted capacity and project scale [9]. Early RE feasibility studies for Gulf countries directed their attention to greenhouse gas emissions as a driver [10,11]. Sustainability and the use of RE is prominent in the 
strategic plans of the country, in terms of targets that will need to be achieved though RE contribution to the overall energy sector. Despite the overall intents, there is still a significant gap in the integration of RE which creates an opportunity for its integration within buildings in the UAE.

The government-sector buildings account for $20 \%$ of the building stock. Therefore, there is focus to adopt energy efficient practices in order to curb energy consumption, as well as establishing better building practices [12]. Governmental buildings aim to lead the way, and are therefore required to achieve at least two pearls [6] by adopting energy efficiency measures and integrating RE systems. Among all public buildings, school buildings have a major social and energy responsibility on account of their educational purpose. Educational facilities are a vital field to implement the sustainability practices and energy efficiency programs. Many countries are developing sustainable regulations and policies for schools building. In order to achieve several national energy efficiency targets, the local governments support all possible and effective initiatives to augment the benefits and the sustainable practices $[13,14]$. Therefore, the Abu Dhabi Educational Council (ADEC), a governmental entity, envisaged a promising 10-year strategic plan (2010-2020) named the "Future Schools Program". This program seeks to construct 100 new schools with a minimum rating of two pearls (60 out of 140 points), and a strongly targeted higher goal of three peals ( 85 out of 140 points) $[15,16]$. To date, 53 schools have been completed that meet the mandatory two pearl requirement. However, only $20 \%$ of these schools have reached the desired target of three pearls. This research aims to uncover the viability of enhancing the green rating performance of school buildings, through renewable energy integration. This research explores the performance of one recently built school under the hot climate of the UAE, which did not reach the desired rating (3 pearls), to serve as a model for the 100 planned schools that are built, or due to be completed by 2020. The aim of this paper is to explore the sustainable performance of one representative school in the context of the UAE's hot climate, with the objective to assess opportunities for an enhanced performance.

\section{Analysis of the School Green Rating System Performance}

A review of green rating achievements of a newly built school prototype was carried out based on the design files and data from the educational council (Figure 2). The school was selected based on its green rating level of achievement (two pearls). The data included architectural drawings, design strategy, and technical specifications. The simulated data of the school performance including building loads, electricity consumption, operational schedules, and used systems. The documentation review revealed that the school already achieved most credits related to passive building envelope components, such as insulation, roof, and glazing systems; and active systems such as LED lighting, sensors, controls, and water efficiency.

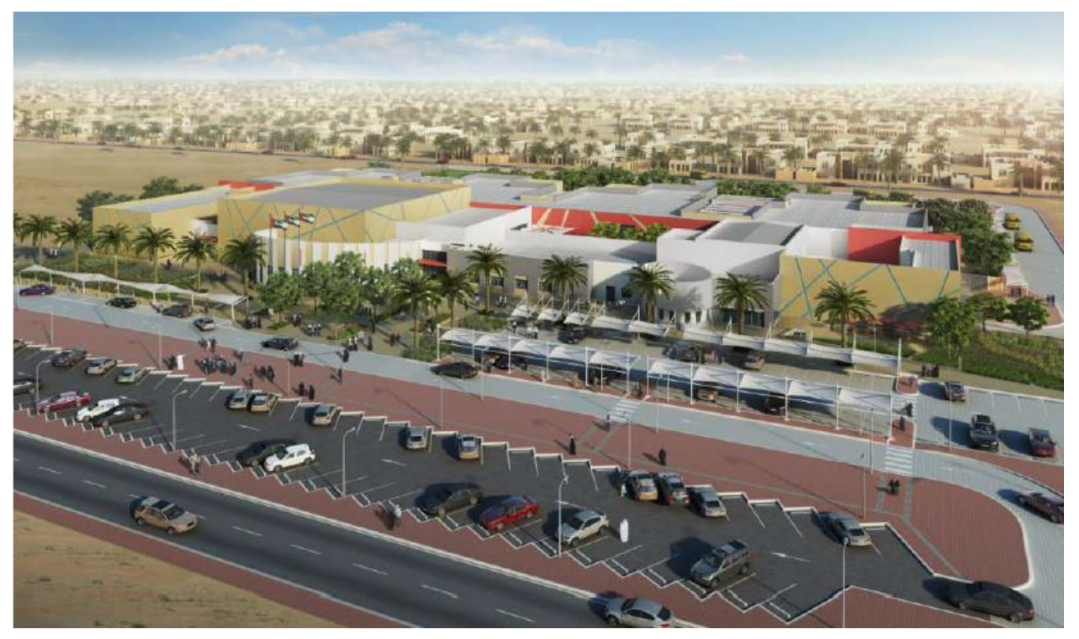

Figure 2. External view of the school [17]. 
The design strategies implemented in the school were based on the local PBRS green rating requirements. A detailed review of the school's two pearl rating revealed that it achieved 81 credit-only 4 points short of achieving the desired level of attainment (three pearls). The analysis revealed that the highest number of unachieved credits (up to $70 \%$ ) were within the Resourceful Energy category, despite this being the most weighted PBRS category. The RE credit distribution comprises of 6 sub-categories, by which 25 credit points were not achieved. The main reasons for this, as indicated in the submission files, were due to the in the lack of expertise offered in the field, therefore this school provides a good opportunity for the investigation of the energy performance enhancement of the building.

This scenario provides a promising potential to explore the use of renewable energy generation. A review of Abu Dhabi's climatic data revealed that the weather remains predominantly hot and humid, with peak summer temperatures reaching $48{ }^{\circ} \mathrm{C}$ and a relative humidity of $90 \%$ [18]. Extreme weather such as this requires extensive air conditioning, which may contribute up to $75 \%$ of a building's energy use [19].

This research explores alternative cooling systems that require less energy input, with the goal of substantially decreasing energy consumption. Solar radiation is plentiful in the UAE, and free to use. Additionally, preliminary assessments have shown a substantial temperature difference of up to $20^{\circ} \mathrm{C}$ between the ground temperature $\left(23^{\circ} \mathrm{C}\right)$ and ambient temperature $\left(48^{\circ} \mathrm{C}\right)$ in the peak summer months, favoring geothermal cooling system [20]. Weather data revealed a yearly solar radiation is $2370 \mathrm{kWh} / \mathrm{m}^{2}$, i.e., $6.5 \mathrm{kWh} / \mathrm{m}^{2}$ per day [21], which favored the choice of an absorption cooling system, and photovoltaic energy generation. Geothermal cooling system have also been found promising to deliver the effective cooling required [21].

The contextual characteristics of the promising renewable energy systems for integration into the selected school building are summarized in Table 1 [22].

The energy produced by the aforementioned systems is compared to the school's baseline energy demand (Table 2), to determine the energy savings and perform the calculation. The predicted energy savings are then converted into credits earned, based on the PBRS guidelines. The cooling system performance is compared with the demand in peak months (May-August) in order to determine the reductions achieved in peak-period cooling capacity and energy use.

Table 1. Renewable energy systems selection in harsh climate.

\begin{tabular}{|c|c|c|c|c|}
\hline System/Criteria & Advantages & Limitations & Performance & Payback Period versus Life Span \\
\hline $\begin{array}{l}\text { Photovoltaic } \\
\text { system [23] }\end{array}$ & $\begin{array}{l}\text { Annual solar } \\
\text { radiation of } \\
2285 \mathrm{kWh} / \mathrm{m}^{2} \text {, } \\
\text { expected energy of } \\
\left.850 \mathrm{~kW} \text { year } / \mathrm{m}^{2}\right) .\end{array}$ & $\begin{array}{l}\text { Dust results in radiation } \\
\text { reduction on panel. } \\
\text { High temperature } \\
\text { results in power losses. }\end{array}$ & $\begin{array}{l}\text { Electrical energy } \\
\text { production of } \\
322 \mathrm{kWh} / \mathrm{m}^{2} \text {-year }[24,25] \text {. }\end{array}$ & $\begin{array}{l}\text { Pay-back period: } 3-5 \text { years [26] } \\
\text { based on unsubsidized tariffs. } \\
\text { Lifespan: } 25-30 \text { years. }\end{array}$ \\
\hline $\begin{array}{l}\text { Solar absorption } \\
\text { cooling system }[27,28]\end{array}$ & $\begin{array}{l}\text { Annual solar } \\
\text { radiation of } \\
182,800 \mathrm{kWh} / \mathrm{m}^{2}\end{array}$ & $\begin{array}{l}\text { High initial cost. } \\
\text { Dust on collectors } \\
\text { results in } \\
\text { radiation reduction. } \\
\text { High temperature } \\
\text { results in power losses. }\end{array}$ & $\begin{array}{l}\text { A cooling energy } \\
\text { production of } \\
1059 \mathrm{kWh} / \mathrm{m}^{2} \text {-year. }\end{array}$ & $\begin{array}{l}\text { Average payback period: } \\
4-10 \text { years. } \\
\text { Lifespan: } 25-35 \text { years. }\end{array}$ \\
\hline $\begin{array}{l}\text { Geothermal } \\
\text { cooling } \\
\text { system }[20,29]\end{array}$ & $\begin{array}{l}\text { Ground temperature } \\
\text { is used to modulate } \\
\text { interior temperature } \\
\text { (difference up to } 20^{\circ} \mathrm{C} \\
\text { during summer) }\end{array}$ & $\begin{array}{l}\text { High initial cost. } \\
\text { Land required to install } \\
\text { the loop. } \\
\text { Lower temperature } \\
\text { gradient in } \\
\text { moderate seasons. }\end{array}$ & $\begin{array}{l}\text { Cooling energy } \\
\text { delivered by } \\
46 \mathrm{kWh} / \text { year-m length } \\
\text { of borehole [30]. }\end{array}$ & $\begin{array}{l}\text { Average payback period: } \\
7-10 \text { years according to the } \\
\text { system size. } \\
\text { Life span: up to } 50 \text { years. }\end{array}$ \\
\hline
\end{tabular}


Table 2. Baseline energy consumption data for the school building [17].

\begin{tabular}{ccc}
\hline System & Peak Capacity (kW) & Annual Energy Consumption (MWh) \\
\hline Space cooling (peak months) & 360.5 & 777.6 \\
Heat rejection & 49.4 & 151 \\
Space heating & 79.7 & 0.066 \\
Pumping energy & 42.8 & 105.7 \\
Interior Fans & 304.6 & 276.9 \\
Interior Lighting & 188.3 & 410 \\
Service Water Heating & 200.0 & 231.8 \\
Receptacle/Process & 167.5 & 252 \\
Equipment & 1392.9 & 2206 \\
Total & &
\end{tabular}

\section{Methodology}

A transient simulation model is developed using Transient Systems Simulation (TRNSYS) software, employing Typical Meteorological Year (TMY) weather data for Abu Dhabi to predict energy performance for the proposed renewable energy systems [31]. TRNSYS simulation program has been widely used in literature, and has been proven as an effective program for simulating geothermal systems [32-34], absorption cooling [35-37] and photovoltaic systems [38-40]. A dynamic model that couples the solar cooling system with the building was developed in TRNSYS to assess its performance in an office building in Tunisia [41]. The model predicted a primary energy savings up to $82.3 \%$ compared to a classic air conditioning system, resulting in a $\mathrm{CO}_{2}$ emissions savings of $2947 \mathrm{~kg}$ [41]. In another study, a solar powered absorption cycle was modeled in TRNSYS, employing evacuated tube collectors coupled with a $10 \mathrm{~kW}$ ammonia-water absorption chiller. The results showed a cost and energy saving of up to $24.5 \%$ and $35.3 \%$, respectively [42]. A desiccant cooling system and geothermal heat pump used together in a solar hybrid desiccant air conditioning system were tested using TRNSYS software in Shanghai. Under typical weather condition, the solar driven desiccant cooling unit achieved an average cooling capacity of $70 \mathrm{~kW}$, contributing up to $31.4 \%$ of the cooling capacity of the system [43]. A TRNSYS model has been developed to simulate both winter and summer period. Results showed that using these systems reduced the payback from 14 years to 1.2 years, with the Primary Energy Savings of about $90 \%$ [44].

The PV and absorption cooling systems are based on size of roof area available to install the PV panels and thermal collectors. Three types of PV systems, namely polycrystalline silicon, mono-crystalline silicon, and amorphous silicon, are preliminary assessed using the manufacturer's data sheets. The analysis revealed that mono-crystalline PV is the most suitable system. This is due to its high efficiency of up to $20 \%$ supporting building integration, and low temperature-based power loss coefficient (up to $0.38 \%$ ), making it favorable in hot climates [45]. The geothermal heat exchanger is chosen based on the size of the land area available around the school to install the loop. The TRNSYS model of the three systems included several building parameters used for modeling. It included parameters for a building envelope, HVAC and plug loads.

\section{Results and Discussion}

\subsection{Photovoltaic System Performance}

The PV module is tested at various slopes and azimuth angles to represent different pitch angles and orientations during building integration, either driven by need or design choice. Figure 3 shows energy produced by $\mathrm{PV}$ integrated to building at pitch angles of $0^{\circ}$ representing flat roof, $24^{\circ}$ representing latitude pitch, $45^{\circ}$ representing regular building pitch, and $90^{\circ}$ representing building vertical facade. 


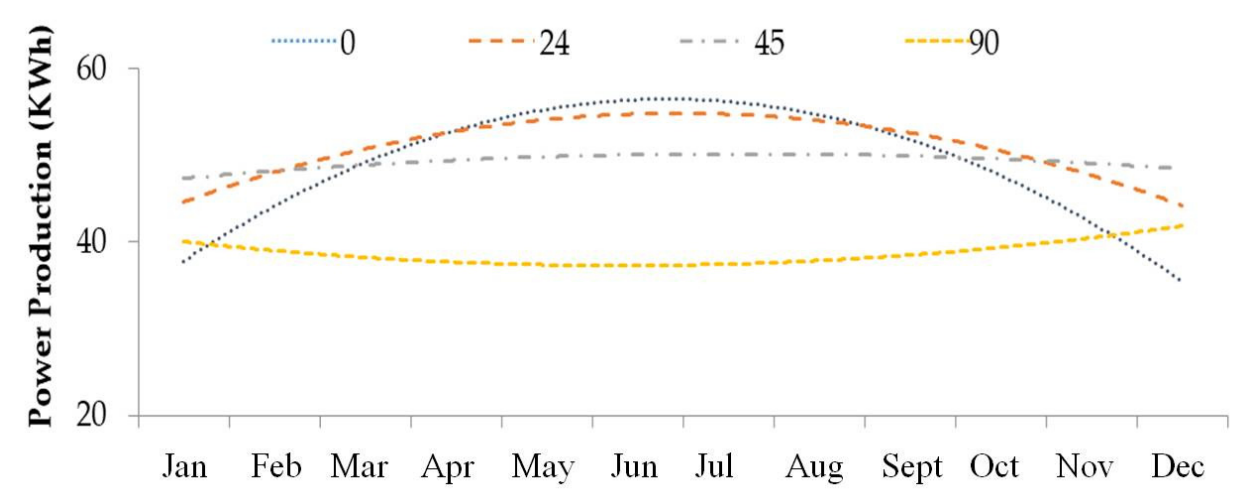

Figure 3. Monthly energy produced per panel at various Photovoltaic (PV) slopes representative of different building integration schemes.

The highest variation in power output is observed at $0^{\circ}$, for which the power output is lowest in winter (December-January) and highest in summer (April-August). This trend can be attributed to the sun position, which moves near zenith up to $18^{\circ}$ in summer and shifts away from zenith up to $30^{\circ}$ in winter, inducing a substantial drop in output. In summer, the incident radiation is nearly normal to the plane of the PV panel at horizontally integrated panels $\left(0^{\circ}\right)$, while in winter the incident radiation is substantially off normal at the same inclinations. The PV panel produces consistently lower power at $90^{\circ}$ fundamentally due to larger deviation of incident angle. At $24^{\circ}$, the energy produced remains higher during most of the months (apart from winter) due to lower solar angles. At $45^{\circ}$, the highest energy production is witnessed during winter, while a substantial decrease is observed in summer. All of these observations are in agreement with previous findings [46,47]. Architecturally, integrating PV at $0^{\circ}$ offers ease of installation, as no additional cost is incurred for structural support, in contrast to sloped $\mathrm{PV}$. However, at $0^{\circ}$ slope the PV panel is prone to increased dust retention compared to the tilted PV, as dust particles on tilted panels can slide down off the panels under gravity.

These results reveal that energy production peaks at different panel slopes during different times of year, suggesting that the PV slope should be adjusted monthly, or at least seasonally, to enhanced energy production. The annual energy production for conventional fixed slopes compared to the monthly adjustable slopes is presented in Figure 4. It can be observed that the adjustable slope improves the power by $3 \%$ output compared to the optimal fixed sloped $\left(24^{\circ}\right)$.

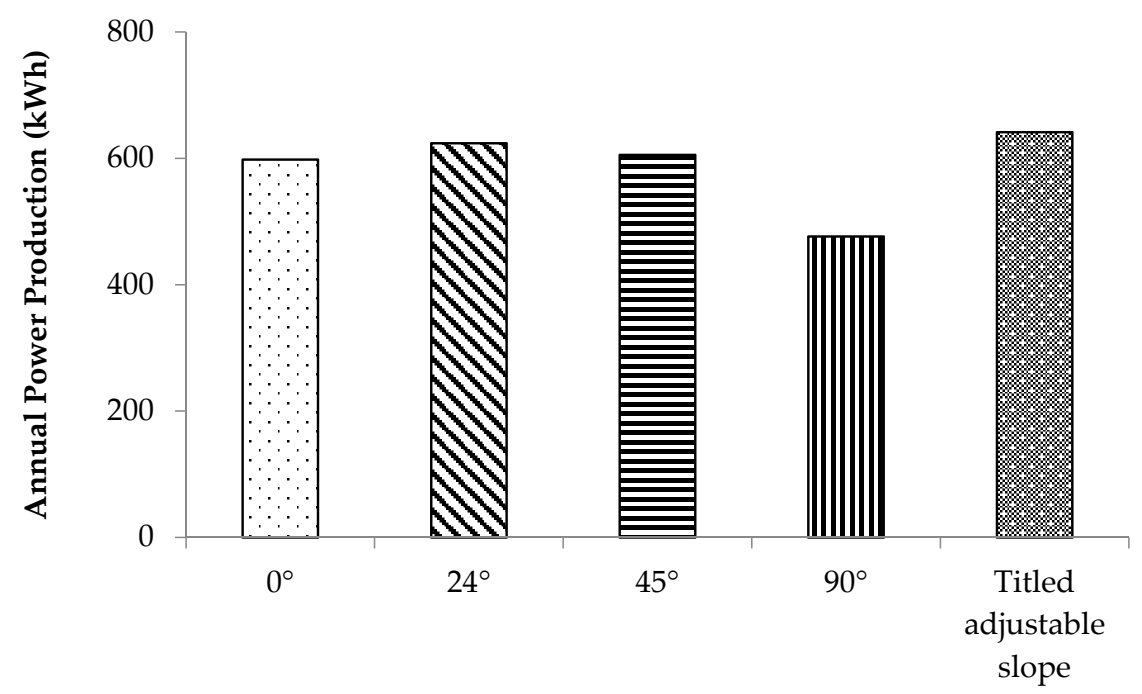

Figure 4. Annual power production per panel $(\mathrm{kWh})$ for different static slope angles, and an optimized adjustable slope design. 
The optimum PV orientation is reported to be exactly southerly in the northern hemisphere, represented by $0^{\circ}$ [48]; however, the energy loss incurred by deviating from the optimum orientation is not well known. The building configuration varies substantially depending on design demands, and architects are often compelled to select a sub-optimal azimuthal orientation in order to adhere to the building design, facilitate mobility, or maintain symmetry. In order to predict PV performance due to sub-optimal azimuth orientation, the energy produced from a PV panel with an azimuth angle varying from 90 to $-90^{\circ}$ (with an interval of $45^{\circ}$ ) is presented in Figure 5.

It can be observed that $0^{\circ}$ yields the highest energy production, while declines of $24 \mathrm{kWh} / \mathrm{m}^{2}$ at $45^{\circ}$ (Southwest) and $45^{\circ}$ (Southeast) and $65 \mathrm{kWh} / \mathrm{m}^{2}$ at $90^{\circ}$ (West) and $-90^{\circ}$ (East) are observed. In order to provide optimal PV power penetration for the school building, half of the available roof area is allocated to PV installation reserving the rest for PV shading and mobility requirements for maintenance. Thus, the total area covered by PV panels was found to be $555 \mathrm{~m}^{2}$ that can house $342 \mathrm{PV}$ panels. The PV array produces 209 MWh of energy, which makes up 10\% of the total yearly energy consumption of the school in 2016.

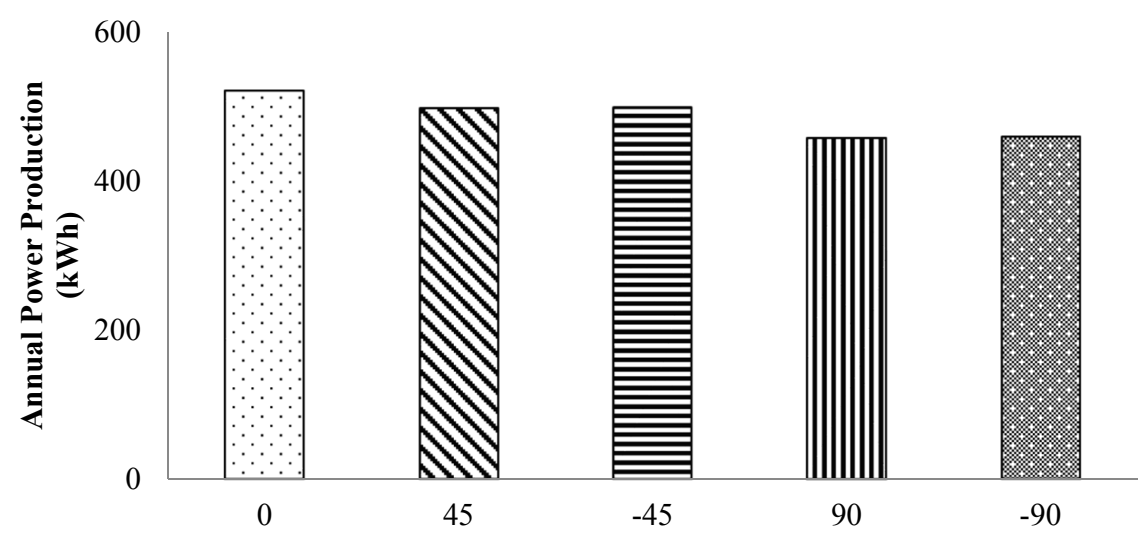

Figure 5. Total annual power production $(\mathrm{kWh})$ for different PV panel azimuth angles for at latitude angle of $24^{\circ}$.

\subsection{Solar Absorption Chiller Performance}

The absorption cooling system is designed to deliver $10 \%(36 \mathrm{~kW})$ of the building peak cooling capacity of $360 \mathrm{~kW}$. Considering the typical UAE peak solar radiation intensity of $1 \mathrm{~kW} / \mathrm{m}^{2}$ [21] and absorption cooling system efficiency of $40 \%,[49,50]$ a typical thermal collector of $3 \mathrm{~m}^{2}$ area can produce $1.2 \mathrm{~kW}$ of cooling power. Thus, an absorption cooling system comprising of 30 collectors covering $90 \mathrm{~m}^{2}$ of roof area would be required to generate $36 \mathrm{~kW}$ of cooling power. The proposed absorption system is simulated with varying concentration ratios (i.e., the aperture area: receiver surface area ratio) and inlet fluid flow rate to achieve the desired fluid temperature of $200{ }^{\circ} \mathrm{C}$ at the collector outlet deemed safe for building integration [51].

The results show that as the concentration ratio increases from 5 to 25 , the temperature of the fluid at collector outlet increases from 150 to $580^{\circ} \mathrm{C}$ and the energy delivered increases from $2258 \mathrm{kWh}$ to $58,600 \mathrm{kWh}$. The optimal temperature of $200^{\circ} \mathrm{C}$ [51], is achieved at a concentration ratio of 10 delivering 24,500 kWh (Figure 6a).

The water flow rate through the solar collector affects its useful thermal energy gain and, consequently, the amount of cooling produced. Optimal system operation therefore depends on achieving a balance between the temperature of the collector and the useful energy production. Simulations are conducted in sequential order, maintaining a collector temperature above $200{ }^{\circ} \mathrm{C}$ through the use of optimal flow rates. A collector temperature of $618^{\circ} \mathrm{C}$ (much higher than optimal $200{ }^{\circ} \mathrm{C}$ ) is achieved at $2 \mathrm{~kg} / \mathrm{h}$ and produces $10.56 \mathrm{kWh}$ of useful energy. With increasing flow rate, the peak collector 
temperature decreased, while paradoxically the useful energy gain increased. A collector temperature of $200{ }^{\circ} \mathrm{C}$ is achieved at a flow rate of $8 \mathrm{~kg} / \mathrm{h}$, producing $12.11 \mathrm{kWh}$ of useful energy (Figure $6 \mathrm{~b}$ ).

The proposed absorption cooling system consists of a thermal collector array, covering a net area of $90 \mathrm{~m}^{2}$, and employs Fresnel lenses to achieve the concentration ratio of 10, and a water circuitry system to maintain a flow rate of $8 \mathrm{~kg} / \mathrm{h}$ per collector. The system produced 150,505 kWh/year of cooling energy, which is equivalent to $19.35 \%$ of the annual cooling energy consumption and $7.2 \%$ of the total annual energy consumption of the school.
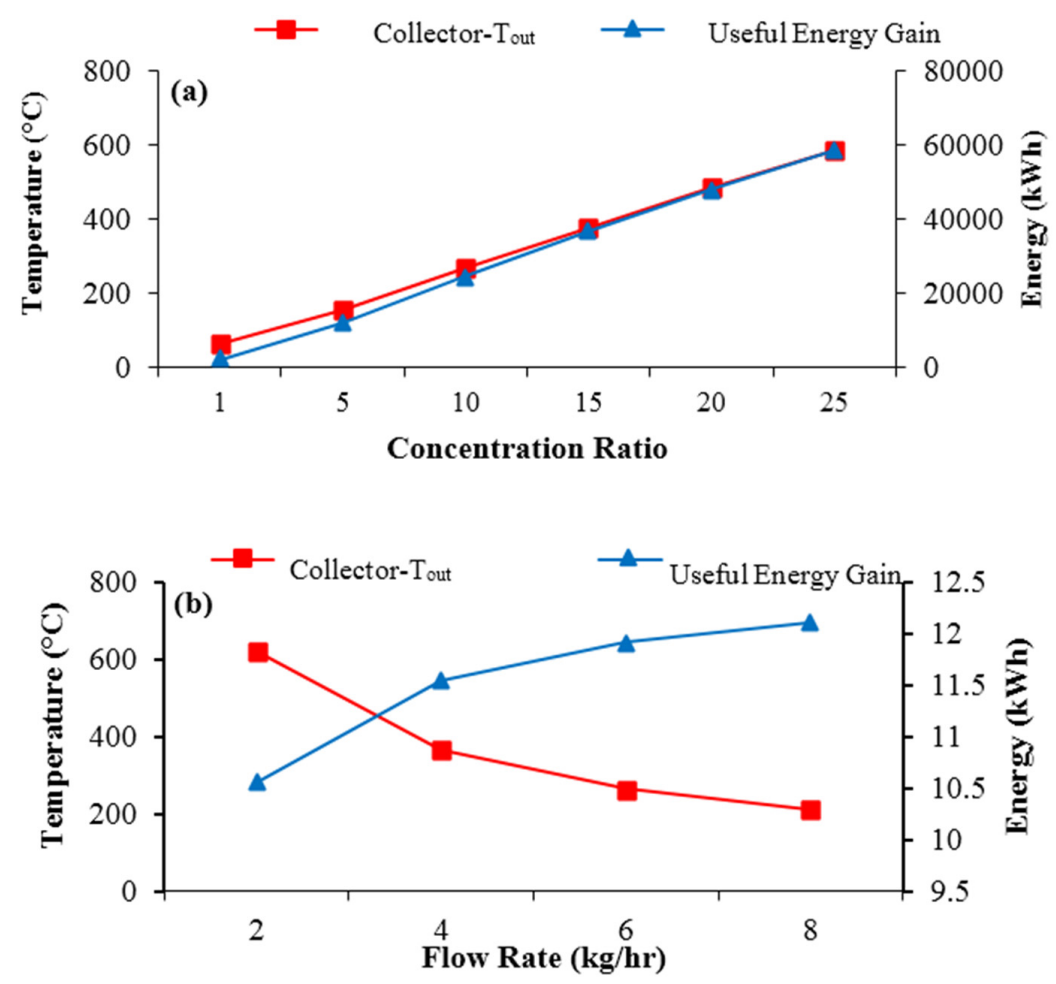

Figure 6. Energy and collector outlet temperature produced by the simulated absorption cooling system under various concentration ratios (a) and fluid flow rates (b) in 2016.

\subsection{Geothermal System Performance}

The geothermal cooling system is preliminarily assessed by comparing the ground temperature at a depth of $5 \mathrm{~m}$ to the minimum and maximum air temperatures in Abu Dhabi, as shown in Figure 7. This analysis reveals that the yearly ground temperature fluctuates between $24^{\circ} \mathrm{C}$ and $26^{\circ} \mathrm{C}$, which offers huge potential as an ambient heat sink, as peak summer air temperature measures up to $48^{\circ} \mathrm{C}$.

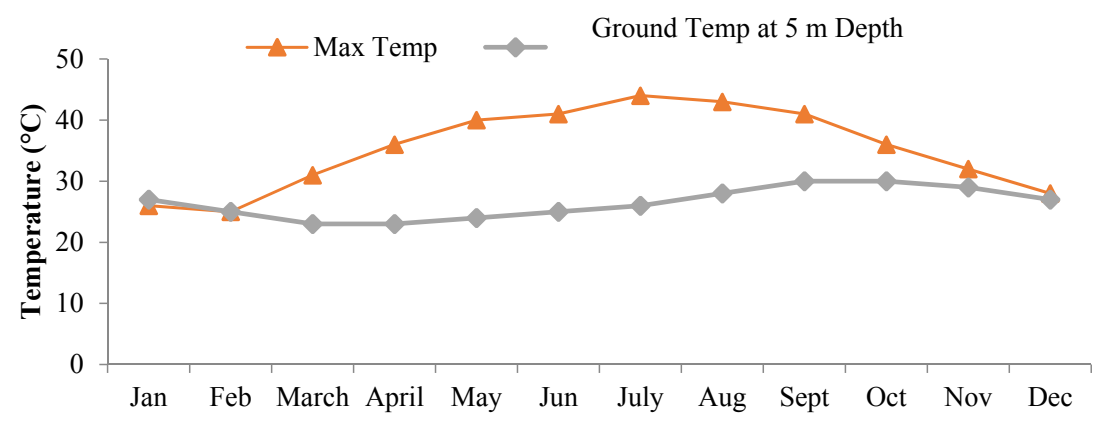

Figure 7. Peak ambient air temperature and ground temperature at a depth of $5 \mathrm{~m}$. 
The parametric influences on the geothermal system are studied to optimize the system energy output (Table 3).

The geothermal system output is monitored in terms of inlet and outlet fluid temperatures, fluid-to-ground heat transfer rate, and the amount of energy delivered representating the cooling produced. The simulation results of nine consecutive representative days in the peak summer month of July are expressed as outlet fluid temperature and energy produced.

The pipe length of the horizontal heat exchanger $(2000 \mathrm{~m})$ is calculated based on the available land area. The effect of fluid flow rate is evaluated from $400 \mathrm{~kg} / \mathrm{h}$ to $4400 \mathrm{~kg} / \mathrm{h}$ in increments of $400 \mathrm{~kg} / \mathrm{h}$. The results show that the energy delivered increases with increasing flow rate up to $2800 \mathrm{~kg} / \mathrm{h}$, delivering $22 \mathrm{MWh}$ of cooling energy during peak months (Figure 8).

Table 3. Parameters and values pertaining to the geothermal system.

\begin{tabular}{cc}
\hline Parameters & Values \\
\hline Fluid Flow rate & $400-4400 \mathrm{~kg} / \mathrm{h}$ in increments of $400 \mathrm{~kg} / \mathrm{h}$ \\
Pipe Length & $200-2800 \mathrm{~m}$ in increments of $200 \mathrm{~m}$ \\
Pipe Diameter & 1 inch, 1.25 inches, 1.5 inches, 2 inches \\
Pipe Material & Aluminum, Copper, Polyethylene \\
Pipe Depth & $3 \mathrm{~m}, 4 \mathrm{~m}, 5 \mathrm{~m}, 6 \mathrm{~m}, 7 \mathrm{~m}$ \\
Pipe Spacing & $0.25 \mathrm{~m}, 0.5 \mathrm{~m}, 0.75 \mathrm{~m}, 1 \mathrm{~m}$ \\
\hline
\end{tabular}

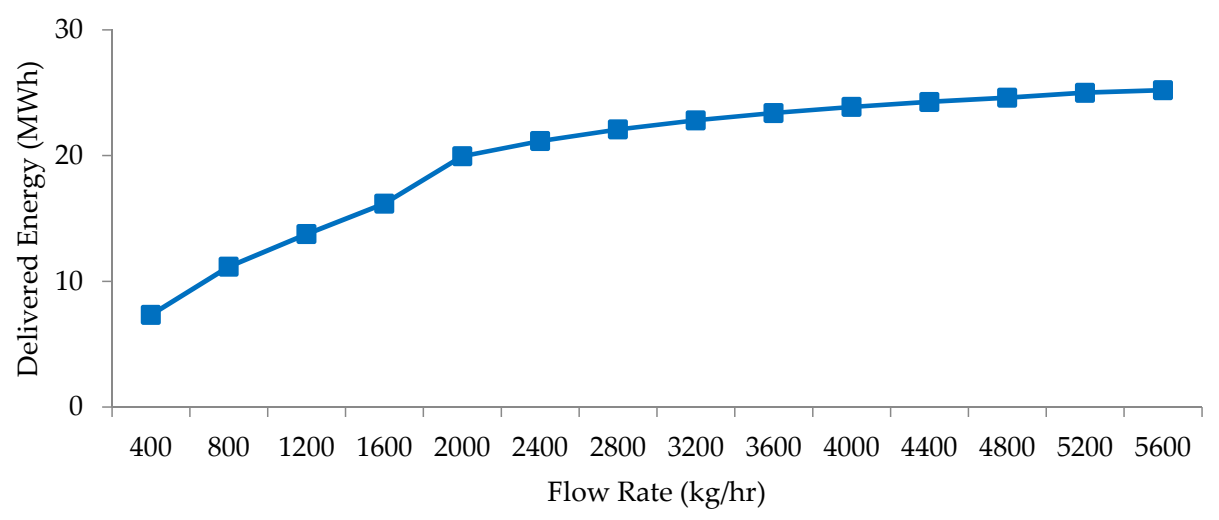

Figure 8. Delivered energy for various pipe flow rates.

The performance of three heat-exchanger materials (i.e., aluminum, copper, and polyethylene) are compared in terms of the amount of heat removed as shown in Figure 9a. Aluminum has a thermal conductivity of $237 \mathrm{~W} / \mathrm{m} \cdot \mathrm{K}$, copper has a thermal conductivity of $401 \mathrm{~W} / \mathrm{m} \cdot \mathrm{K}$, and polyethylene has a thermal conductivity of $0.33 \mathrm{~W} / \mathrm{m} \cdot \mathrm{K}$. The delivered energy range of variation is between 22,100 MWh to $22,400 \mathrm{MWh}$, showing a negligible variation. However, polyethylene pipe is expected to last longer due to its higher resistance to corrosion. Thus, polyethylene is used as the heat exchanger material for further simulations. The effect of pipe depth on delivered energy is determined for depths ranging from $3 \mathrm{~m}$ to $7 \mathrm{~m}$, in increments of $1 \mathrm{~m}$ [52]. The results in Figure $9 \mathrm{~b}$ show an increase in delivered energy with increasing pipe depth up to $5 \mathrm{~m}$ producing up to $39 \mathrm{MWh}$ cooling energy. The effect of heat exchanger loop spacing on the delivered energy is determined ranging from $0.25 \mathrm{~m}$ to $1 \mathrm{~m}$, shown in Figure 9c. The energy delivered increases with increasing inter-loop spacing, reaching $39 \mathrm{MWh}$ at $1 \mathrm{~m}$ spacing. Finally, the effect of pipe diameter is determined ranging from 0.75 inch to 2 inches, as shown in Figure 9d. The results indicate that the energy delivered increases with increasing pipe diameter, reaching $22 \mathrm{MWh}$ at a 2-inch diameter.

The optimal arrangement reduced the leaving air temperature by $12{ }^{\circ} \mathrm{C}$, thus resulting in a $5.8 \%$ reduction in annual cooling energy, and a $2.8 \%$ reduction in annual energy consumption. 
The temperature is not expected to increase by the geothermal loop, since the earth has infinite thermal mass, so the heat will eventually dissipate into the earth. Thus, it is least likely that the temperature of the earth will rise. Additionally, the spacing between pipes is $1 \mathrm{~m}$; therefore, the temperature will spread between the pipes. Moreover, the heat exchanger has minimal effect on the earth temperature compared to the solar radiation, which is much higher that the earth temperature. Ground temperature below a particular depth remains relatively constant throughout the year; due to the high thermal inertia of the soil [53]. At a sufficient depth, the ground temperature is always lower than the outside air in summer. When Ground Source Heat Pump (GSHP) is used, the temperature difference between the outside air and the ground is utilized to dump heat into the ground during summer to provide cooling. Our findings are in line with a research done in similar climates as the UAE, in which a mathematical model was developed and validated experimentally coupling the Solar Cooling System (SCS) with a Geothermal Heat Exchanger (GHX) in California, USA [52]. The results show that a $12.30 \mathrm{~kW}$ cooling capacity SCS would be necessary to satisfy the maximum cooling load requirement during the summer. Additionally, between 10 and $23 \%$ of the energy demand was met by the systems [52].

Recently, some buildings started integrating geothermal system in the UAE as a pre-cooling system, and are reported to be effective [54]. In particular, Sheikh Zayed Learning Center, a museum in Al Ain city, UAE, integrated geothermal system and was able to achieve a five pearls, based on the PBRS system, and was certified a LEED platinum rating [54].
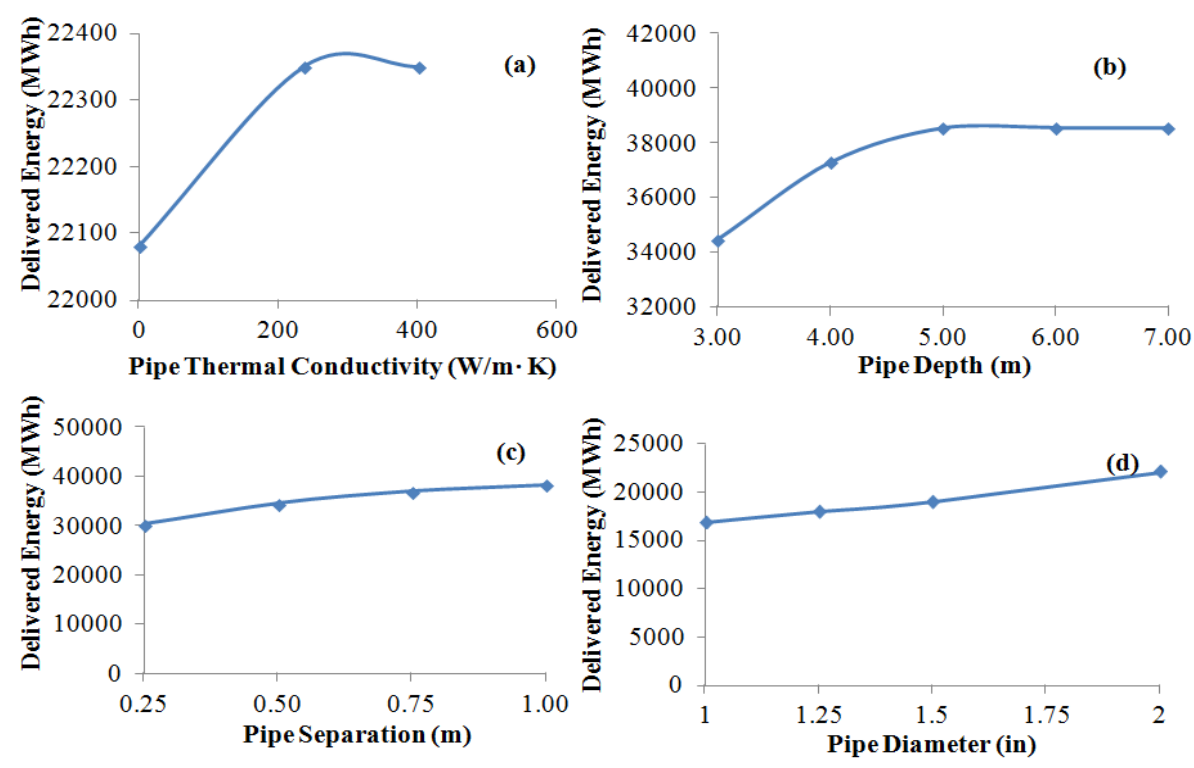

Figure 9. The parametric influence of pipe material (a) pipe depth (b) pipe spacing (c) and pipe diameter $(\mathbf{d})$ on the delivered energy.

\section{Credit Enhancement Verification of the Local Green Rating System}

In order to verify the result of the study with the local PBRS rating system, an analysis has been done to calculate the contribution of the studied systems to the overall credits achieved.

The number of RE- 1 credits achieved through the integration of the renewable energy systems, discussed in Section 4, are calculated by applying Equation (1) which comes from Estidama manual:

$$
R E-1=\frac{100 \times 2,088,493.2\left(\frac{\mathrm{kWh}}{\mathrm{yrh}}\right)-1,684,467.2\left(\frac{\mathrm{kWh}}{\mathrm{yrh}}\right)}{2,088,493.2\left(\frac{\mathrm{kWh}}{\mathrm{yrh}}\right)}=19.35 \%
$$

The proposed systems reduce building energy consumption by $19.35 \%$, earning 4 additional credits points, and thus achieving all of the 5 credits allocated to the RE category in the PBRS. 
The Estidama PBRS also awards additional RE- 5 credits for peak cooling capacity reductions as given in Equation (2). The annual average electrical load is calculated in Equation (3).

$$
\begin{aligned}
\text { Peak Reduction } & =\frac{\text { Peak Load }}{\text { Average Electrical Load }} \\
\text { Annual Average Electrical Load } & =\frac{\text { Cooling Load } \mathrm{kWh}}{180 \text { days } \times 24 \frac{\mathrm{hr}}{\text { day }}}+\frac{\text { Other Loads } \mathrm{kWh}}{180 \text { days } \times 9 \frac{\mathrm{hr}}{\mathrm{day}}}
\end{aligned}
$$

A system achieving a peak cooling load-to-average electrical load ratio of 1.8 or below qualifies for two additional credits. The proposed systems reduce the peak-cooling-to-average load ratio to 1.7 , thus earning two additional credits. The school analyses in this article is already producing $5 \%$ of its energy through RE systems. Adding 19.3\% energy generated from the proposed three systems would bring the total RE penetration to $24.3 \%$, nearly reaching the ceiling of $25 \%$ allowed by the PBRS. This would lead to additional 14 credit points, increasing the school's current rating from 81 to 95 credit points: Thus enabling it to reach the desired three pearl rating (which requires a minimum of 85 credit points).

\section{System Integration}

The school building is being served by a central chiller as a cooling system. The geothermal and absorption chiller energy systems are designed to work together with the existing cooling system of the school. Solar thermal panels, used to heat water, would be used directly for heating water in the building during winter, and to pass the water to the absorption chiller, to cool the building during summer (Figure 9). During summer, the air coming from outside would be monitored as it passes through geothermal system, and is then cooled through the Air Handling Unit (AHU) before entering the building. At the same time, the hot water passes through the absorption chiller system to cool, and then passes through the AHU before being used. If hot water entered the absorption chiller, it will be cooled down but still will not be comfortable, thus, it would enter the chiller compressor to be chilled water, before passing through the AHU, ready to be used in the school. During winter, the air will go directly to the AHU and there will be no cooling demand, thus the thermal panels will be used to heat the water inside the building (Figure 10).

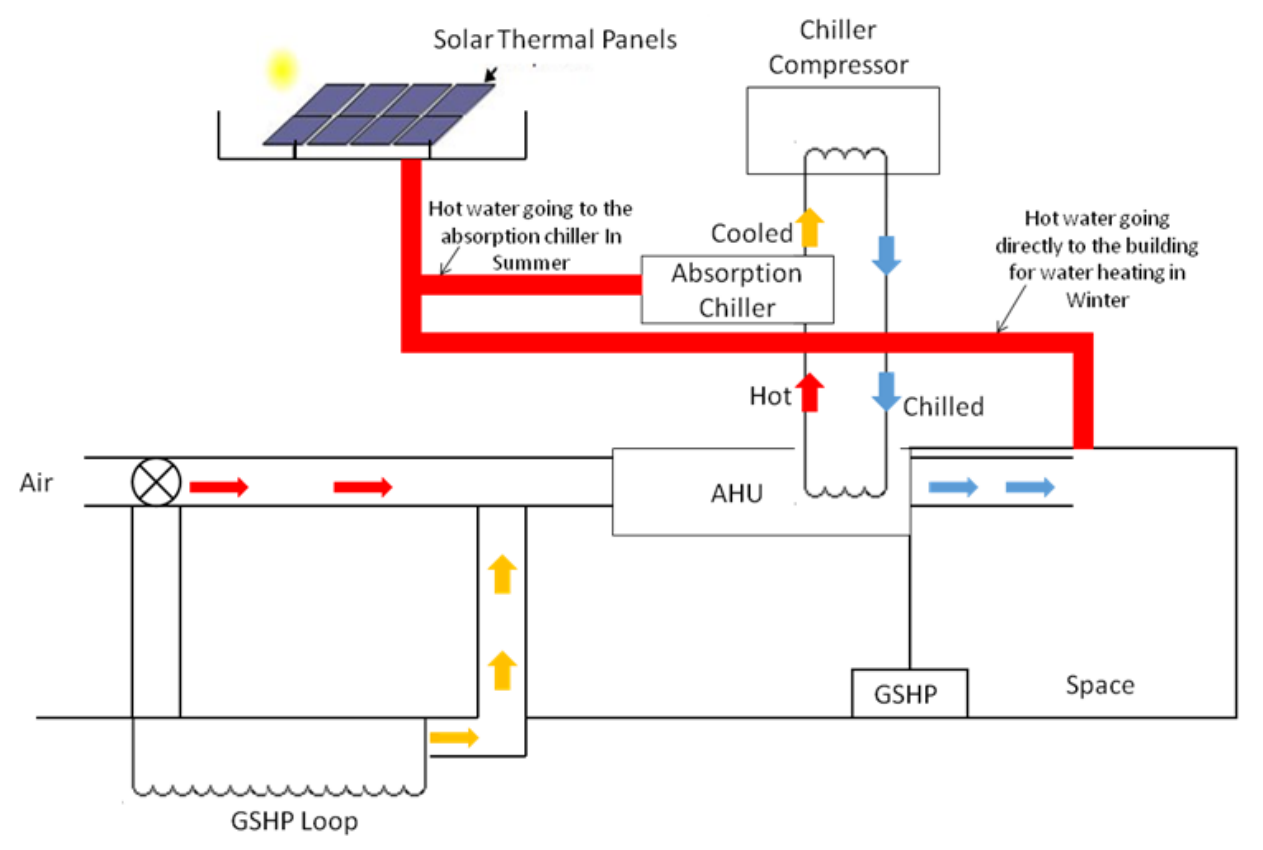

Figure 10. Renewable energy system integration. 


\section{Conclusions}

This paper investigates opportunities of integrating renewable energy strategies to enhance the energy performance of governmental schools, under the harsh climate of the United Arab Emirates. Specifically, it aims to improve the local green building rating performance of a public schools in Abu Dhabi (UAE) by taking it from two pearls to three pearls. This is done through gaining credits in the PBRS' Resourceful Energy category, which represent one-fourth of the obtainable credits. This particular category has not been optimally integrated in the newly built public buildings, despite its potential.

The technical feasibility of renewable energy systems, namely photovoltaic, solar-powered absorption chiller and geothermal systems, were studied. The systems were evaluated using TRNSYS Simulation Software under UAE climatic conditions to test their performance. Relevant parameters and variables in each energy system were optimized in order to maximize energy savings, while remaining grounded in qualitative design terms, special requirement, and cost constraints. The geothermal system yields an annual cooling energy reduction of $5.8 \%$, and a total energy reduction of $2.2 \%$. The solar absorption cooling system results in $19.35 \%$ reduction in annual cooling energy use, and $7.2 \%$ reduction in total annual energy use. The photovoltaic system contributes $10 \%$ of the total energy consumption (or a 10\% energy savings). The total energy savings from the combined three systems can reach $19.35 \%$, which leads to an additional 14 PBRS credit points. The rating enhancement is found feasible in terms of energy, and special provisions involving photovoltaic, solar-powered absorption cooling, and geothermal renewable energy systems. Thus, integrating these systems will allow the school to improve its pearl rating from the current level of performance to the next i.e., from two pearls to the desired three pearls. Furthermore, this study considered the RE system integration into the existing cooling system of the school. The investigated solar systems hold an applicability enhancement potential that spans to most similar buildings under the same, or similar settings.

Author Contributions: All authors conceived the subject of this paper, J.A.D. carried the literature review and the simulations and wrote the initial manuscript. K.T.A. and A.H. verified the scholastic depth of the paper, carried out a critical review of the structure and content, and also supervised the analysis and findings of this work. All authors discussed the results and contributed to the final write up.

Funding: The authors gratefully acknowledge financial support from the United Arab Emirates University through the Emirates Centre for Energy and Environment grant number [31R054] and grant number [31R102].

Conflicts of Interest: The authors declare no conflict of interest.

\section{References}

1. Statistics-Center. Energy and Water Statistics. 2015. Available online: http://ecocci.org/images/stories/ ECO_data/Announcement/Energy_and_Water_Statistics_2015.pdf (accessed on 12 September 2017).

2. Lin, M.; Afshari, A.; Azar, E. A data-driven analysis of building energy use with emphasis on operation and maintenance: A case study from the UAE. J. Clean. Prod. 2018, 192, 169-178. [CrossRef]

3. Mokhtar, M.; Ali, M.T.; Bräuniger, S.; Afshari, A.; Sgouridis, S.; Armstrong, P.; Chiesa, M. Systematic comprehensive techno-economic assessment of solar cooling technologies using location-specific climate data. Appl. Energy 2010, 87, 3766-3778. [CrossRef]

4. Friess, A.W.; Rakhshan, K. A review of passive envelope measures for improved building energy efficiency in the UAE. Renew. Sustain. Energy Rev. 2017, 72, 485-496. [CrossRef]

5. Estidama. Available online: http://estidama.upc.gov.ae/estidama-and-pearl-rating-system.aspx?lang=en-US (accessed on 22 January 2017).

6. Estidama. The Pearl Rating System for Estidama. Available online: http:/ / estidama.upc.gov.ae/template/ estidama/docs/PBRS\%20Version\%201.0.pdf (accessed on 18 April 2016).

7. Sgouridis, S.; Griffiths, S.; Kennedy, S.; Khalid, A.; Zurita, N. A sustainable energy transition strategy for the United Arab Emirates: Evaluation of options using an integrated energy model. Energy Strategy Rev. 2013, 2, 8-18. [CrossRef] 
8. Sgouridis, S.; Abdullah, A.; Griffiths, S.; Saygin, D.; Wagner, N.; Gielen, D.; Reinisch, H.; McQueen, D. Re-mapping the uae's energy transition: An economy-wide assessment of renewable energy options and their policy implications. Renew. Sustain. Energy Rev. 2016, 55, 1166-1180. [CrossRef]

9. Alnaser, W.E.; Alnaser, N.W. The status of renewable energy in the GCC countries. Renew. Sustain. Energy Rev. 2011, 15, 3074-3098. [CrossRef]

10. Doukas, H.; Patlitzianas, K.D.; Kagiannas, A.G.; Psarras, J. Renewable energy sources and rationale use of energy development in the countries of GCC: Myth or reality? Renew. Energy 2006, 31, 755-770. [CrossRef]

11. Patlitzianas, D.K.; Doukas, H.; Psarras, J. Enhancing renewable energy in the Arab states of the gulf: Constraints \& efforts. Energy Policy 2006, 34, 3719-3726.

12. Taleb, H.; Al-Saleh, Y. Applying energy-efficient water heating practices to the residential buildings of the united arab emirates. Int. J. Environ. Sustain. 2014, 9, 35-51.

13. Berg, A. Not roadmaps but toolboxes: Analysing pioneering national programmes for sustainable consumption and production. J. Consum. Policy 2011, 34, 9-23. [CrossRef]

14. Cincera, J.; Krajhanzl, J. Eco-schools: What factors influence pupils' action competence for pro-environmental behaviour? J. Clean. Prod. 2013, 61, 117-121. [CrossRef]

15. Central-Intelligence-Agency. United Arab Emirates Electricity Consumption. Available online: http:/ / www. indexmundi.com/g/g.aspx?c=tc\&v=81 (accessed on 19 January 2017).

16. ADEC. Educational Facilities Design Manual; Abu Dhabi Education Council: Abu Dhabi, UAE, 2010.

17. ADEC. Sheikha Bint Sroor Public School Data; Dakheel, J.A., Ed.; ADEC: Abu Dhabi, UAE, 2016.

18. World-Weather. Abu Dhabi Monthly Climate Average, United Arab Emirates. Available online: https://ar. worldweatheronline.com/abu-dhabi-weather-averages/abu-dhabi/ae.aspx (accessed on 14 January 2017).

19. Radhi, H. Evaluating the potential impact of global warming on the uae residential buildings-A contribution to reduce the $\mathrm{CO}_{2}$ emissions. Build. Environ. 2009, 44, 2451-2462. [CrossRef]

20. Climate-Consultant. Ground Temperatures of Abu Dhabi. In Climate Consultant, version 5.5; United States Department of Energy: Washington, DC, USA, 2017.

21. Hasan, A.; Sarwar, J.; Alnoman, H.; Abdelbaqi, S. Yearly energy performance of a photovoltaic-phase change material (PV-PCM) system in hot climate. Sol. Energy 2017, 146, 417-429. [CrossRef]

22. Hayter, S.; Kandt, A. Renewable Energy Applications for Existing Buildings; National Renewable Energy Laboratory: Golden, CO, USA, 2011.

23. Walwil, H.M.; Mukhaimer, A.; Al-Sulaiman, F.A.; Said, S.A. Comparative studies of encapsulation and glass surface modification impacts on PV performance in a desert climate. Sol. Energy 2017, 142, 288-298. [CrossRef]

24. Emziane, M.; Al Ali, M. Performance assessment of rooftop PV systems in Abu Dhabi. Energy Build. 2015, 108, 101-105. [CrossRef]

25. Al Ali, M.; Emziane, M. Performance analysis of rooftop PV systems in Abu Dhabi. Energy Procedia 2013, 42, 689-697. [CrossRef]

26. Radhi, H. Energy analysis of façade-integrated photovoltaic systems applied to UAE commercial buildings. Sol. Energy 2010, 84, 2009-2021. [CrossRef]

27. Shirazi, A.; Taylor, R.A.; Morrison, G.L.; White, S.D. A comprehensive, multi-objective optimization of solar-powered absorption chiller systems for air-conditioning applications. Energy Convers. Manag. 2017, 132, 281-306. [CrossRef]

28. Bellos, E.; Tzivanids, C.; Symeou, C.; Antonopoulos, K.A. Energetic, exergetic and financial evaluation of a solar driven absorption chiller-A dynamic approach. Energy Convers. Manag. 2017, 137, 34-48. [CrossRef]

29. Fong, K.F.; Lee, C.K.; Zhao, T.F. Effective design and operation strategy of renewable cooling and heating system for building application in hot-humid climate. Sol. Energy 2017, 143, 1-9. [CrossRef]

30. Salem, A.; Hashim, H. A feasibility of geothermal cooling in Middle East. Latest Trends Sustain. Green Dev. 2010, 105-112.

31. TRNSYS. What Is TRNSYS? Available online: http:/ / www.trnsys.com/ (accessed on 14 February 2017).

32. Chargui, R.; Sammouda, H.; Farhat, A. Geothermal heat pump in heating mode: Modeling and simulation on trnsys. Int. J. Refrig. 2012, 35, 1824-1832. [CrossRef]

33. Cocchi, S.; Castellucci, S.; Tucci, A. Modeling of an air conditioning system with geothermal heat pump for a residential building. Math. Probl. Eng. 2013, 2013, 781231. [CrossRef] 
34. Safa, A.A.; Fung, A.S.; Kumar, R. Heating and cooling performance characterisation of ground source heat pump system by testing and TRNSYS simulation. Renew. Energy 2015, 83, 565-575. [CrossRef]

35. Florides, G.A.; Kalogirou, S.A.; Tassou, S.A.; Wrobel, L.C. Modelling and simulation of an absorption solar cooling system for Cyprus. Sol. Energy 2002, 72, 43-51. [CrossRef]

36. Kim, B.; Park, J. Dynamic simulation of a single-effect ammonia-Water absorption chiller. Int. J. Refrig. 2007, 30, 535-545. [CrossRef]

37. Asim, M.; Dewsbury, J.; Kanan, S. TRNSYS simulation of a solar cooling system for the hot climate of Pakistan. Energy Procedia 2016, 91, 702-706. [CrossRef]

38. Li, Y.; Jing, D. investigation of the performance of photovoltaic/thermal system by a coupled TRNSYS and CFD simulation. Sol. Energy 2017, 143, 100-112. [CrossRef]

39. Vuong, E.; Kamel, R.S.; Fung, A.S. Modelling and simulation of BIPV/T in EnergyPlus and TRNSYS. Energy Procedia 2015, 78, 1883-1888. [CrossRef]

40. Quesada, B.; Sánchez, C.; Cañada, J.; Royo, R.; Payá, J. Experimental results and simulation with TRNSYS of a 7.2 KWp grid-connected photovoltaic system. Appl. Energy 2011, 88, 1772-1783. [CrossRef]

41. Soussi, M.; Balghouthi, M.; Guizani, A.; Bouden, C. Model performance assessment and experimental analysis of a solar assisted cooling system. Sol. Energy 2017, 143, 43-62. [CrossRef]

42. Al-Alili, A.; Hwang, Y.; Radermacher, R.; Kubo, I. Optimization of a solar powered absorption cycle under Abu Dhabi's weather conditions. Sol. Energy 2010, 84, 2034-2040. [CrossRef]

43. Dai, Y.; Li, X.; Wang, R. Theoretical analysis and case study on solar driven two-stage rotary desiccant cooling system combined with geothermal heat pump. Energy Procedia 2015, 70, 418-426. [CrossRef]

44. Angrisani, G.; Diglio, G.; Sasso, M.; Calise, F.; d'Accadia, M.D. Design of a novel geothermal heating and cooling system: Energy and economic analysis. Energy Convers. Manag. 2016, 108, 144-159. [CrossRef]

45. Alchemie. Solar Cells. Available online: http://www.solar-facts-and-advice.com/solar-cells.html (accessed on 13 March 2017).

46. Gunerhan, H.; Hepbasli, A. Determination of the optimum tilt angle of solar collectors for building applications. Build. Environ. 2007, 42, 779-783. [CrossRef]

47. Jafarkazemi, F.; Saadabadi, S.A. Optimum tilt angle and orientation of solar surfaces in Abu Dhabi, UAE. Renew. Energy 2013, 56, 44-49. [CrossRef]

48. Assi, A.; Jama, M.; Al Kathairi, K.; Al Shehhi, I.; Fattahi, S. Predicting the electrical behavior of grid-tied photovoltaic systems in al ain-uae/model and case study. In Proceedings of the 2008 IEEE International Conference on Sustainable Energy Technologies, Singapore, 24-27 November 2008; pp. 443-447.

49. Ernst, W.D.; Shaltens, R.K. Automotive Stirling Engine Development Project; Mechanical Technology, Inc.: Latham, NY, USA, 1997.

50. Kong, X.Q.; Wang, R.Z.; Huang, X.H. Energy efficiency and economic feasibility of CCHP driven by Stirling engine. Energy Convers. Manag. 2004, 45, 1433-1442. [CrossRef]

51. Syed, A.; Izquierdo, M.; Rodriguez, P.; Maidment, G.; Missenden, J.; Lecuona, A.; Tozer, R. A novel experimental investigation of a solar cooling system in Madrid. Int. J. Refrig. 2005, 28, 859-871. [CrossRef]

52. Acuña, A.; Lara, F.; Rosales, P.; Suastegui, J.; Velázquez, N.; Ruelas, A. Impact of a vertical geothermal heat exchanger on the solar fraction of a solar cooling system. Int. J. Refrig. 2017, 76, 63-72. [CrossRef]

53. Lee, K.S. Underground thermal energy storage. In Underground Thermal Energy Storage; Springer: London, UK, 2013; pp. 15-26.

54. IRENA. District Heating and Cooling; IRENA: Abu Dhabi, UAE, 2017.

(c) 2018 by the authors. Licensee MDPI, Basel, Switzerland. This article is an open access article distributed under the terms and conditions of the Creative Commons Attribution (CC BY) license (http://creativecommons.org/licenses/by/4.0/). 